Journal of Transformative Praxis

Vol. 2, No. 1, 2021, pp. 8-18

https://doi.org/10.51474/jrtp.v2i1.520

Received: 10 February, 2020; Revised: 12 May, 2020; Accepted: 22 June, 2020

Original Article

\title{
Journeying Through Informing, Reforming and Transforming Teacher Education: Reflections on Curriculum Images
}

\author{
Sadruddin Bahadur Qutoshi \\ Faculty of Education, Karakorum International University, Pakistan \\ Email: sadruddin.qutoshi@kiu.edu.pk \\ 0000-0003-1630-428X
}

\begin{abstract}
This paper aims to address 'how an auto/ethnographic muse explores informing, reforming and transforming states of teacher education and research practices.' I critique informing and reforming states of teacher education in Pakistan for the limitations associated with these approaches rooted within the colonial system of education. Within these two approaches to education, I share the experiences of teaching, learning, research practices, and beliefs, which could not address a broader view of teacher education. To address the research problem, I applied an unconventional approach to research by using auto/ethnography as a methodological referent within a multi-paradigmatic research design space. In so doing, I used the paradigms of interpretivism, criticalism, postmodernism, and integralism as data referents, which enabled me to capture the lived experiences of my professional lifeworld at different stages. Moreover, I used critical reflections on the experiences as a teacher, teacher educator, and researcher as epistemic techniques to explore, explain and construct meaning out of the perceptions, beliefs, and practices. Perhaps, engaging autobiographically as an approach to knowing deep-seated views and practices and critically reflecting on the embodied values of practices open new ways of being and becoming a transformative learner(s). This paper invites readers to reflect critically on their own deep-seated practices by using such unconventional approaches to research that would enable them to experience a paradigm shift in their thinking, believing, viewing, and doing. I believe that in doing so, practitioners as researchers, with their own embodied values of practice in their professional lives, can transform self/others by creating their own living-educational-theories.
\end{abstract}

Keywords: Auto/ethnography. Living-Theory. Embodied Values. Transformative Teacher Education. Multiparadigmatic Research Design. Critical Self-Reflection.

ISSN: 2717-5081 (Print); 2738-9529 (Online)

Journal Webpages:

(C) The Author, 2021.

1. http://www.kusoed.edu.np/journal/index.php/jtp

2. https://www.nepjol.info/index.php/jrtp/

Published by Kathmandu University School of Education, Hattiban, Lalitpur, Nepal. 


\section{Introduction}

'No matter how good a teacher education program is, at best, it can only prepare teachers to begin teaching.'

(Zeichner \& Liston, 1996, p. 5).

It was a fine Monday morning of February 2013. I arrived at the School of Education, Kathmandu University, Nepal. As a doctoral student from Pakistan having an experience of a traditional as well as a modern view of teaching, learning, and leading in different educational settings, it was my third international exposure to experience learning in a different country. There in Nepal, I joined a group of advanced qualitative researchers, and thus I became a research mentee of a transformative educator. Sharing my views of a traditional state of teacher education and research practices with my mentor and reflecting on it, we called such an approach to education an 'informing' nature of education. The notion behind an informing nature of education is embedded within the philosophy of curriculum as textbooks, teaching as telling, learning as remembering, and research as testing (i.e., to apply a formula either to accept or reject a hypothesis). Perhaps, such an informative state of education hardly contributes to producing learners (with limited knowledge required that focuses on remembering and understanding levels of knowledge acquisition) just to pass their exams for promotion to the next grade level.

Our (I as mentee and Bal as a mentor) discourses on such notions of education and critical reflections enabled me to infer that such an education, according to Bloom's revised taxonomy (Anderson \& Krathwohl, 2001), appears to focus on developing lower-order thinking skills in students as blind followers. Probably, this could be one of the reasons that let Great Britain introduce an education that could produce an obedient labor force in the colonized countries, including the sub-continent (Luitel, 2009). Unfortunately, till now, we carry colonized mindsets and are unable to come out of the notions of education as banking (Freire, 1968). The question is who will find an alternative way to come out of such kinds of educational practices and address the issues of education as transmitting and learning as receiving without any critique.

Such reflections on the practices and meaning-making of the implications for policymakers and practitioners led me to think about teacher education with a holistic lens (i.e., reflecting on informing and reforming the nature of education and thereby envisioning a transforming view). However, here in this paper, I focus only on curricular views, beliefs, and practices to make the meaning of education within the parameters of the curriculum. Thus, engaging with writing narratives on educational leadership, the nature of the curriculum, pedagogical approaches, assessment techniques, and research methods, and reflecting critically on informing or informative view of education helped me to explain an education system that does not help students to apply knowledge in their practical lives. Education as informing focuses on lower-order thinking skills with remembering and understanding only that does not enable learners to go beyond (i.e., applying and analyzing knowledge, skills, and values). My learning through such a critical reflective engagement with an informative nature of education led me to think about yet another view of education that was considered as a reformative education with a modern outlook.

I shared my own experiences as a team member of the curriculum reformers in Pakistan. I explained my experiences of reforms in teacher education in Pakistan and critiqued this modern view of education as well. To me, such kind of reforms in education is a good initiative yet not sufficient approach to education that can appreciate to think beyond and open new avenues for linking middle-order thinking skills (i.e., applying and analyzing knowledge, skills, and values) to higher-order thinking skills (i.e., evaluating and creating new knowledge). In 
my doctoral study, I called this limited view of reformative education in Pakistan the "cosmetic remedies for chronic diseases" (Qutoshi, 2016) in the system of a colonial brand of education. Thus, building on my lived experiences as both an informative practitioner and a reformative curriculum developer in teacher education in Pakistan, I came to realize that envisioning a transformative teacher education and research practices with an emancipatory interest in education for my country (and countries elsewhere in the world with similar educative practices) appears to be a way forward to deal with problems of $21^{\text {st }}$ century to face the challenges of the digital age (Bohman \& Rehg, 2014; Habermas, 972).

Before embracing an illuminating view of transformative education for liberation and empowerment, I had had wonderful experiences of discussions and discourses with my mentor and other colleagues/professors at Kathmandu University School of Education (KUSOED), Nepal. There, I came to realize that education, in its true spirit, is an ongoing and lifelong learning process using a self-critically reflective lens. Perhaps, a self-critically reflective lens has the power to explore 'high-deep' (Saldana, 2015) inside (i.e., the personal world of a practitioner) and enables to challenge taken-for-granted ways of being and becoming. In doing so, it may be possible to develop new perspectives by challenging and disrupting the old perspective, which Jack Mezirow calls transformative learning (Mezirow, 1978).

Here, I still remember our discussions on transformative learning and research at KUSOED with my supervisor, who once said, 'Sadruddin, transformation is not a fixed point of arrival at a destination. Rather, it is an ongoing process of being aware of self/others, raising consciousness, and developing capacities to create conditions that can engage with an emancipatory view for teacher education and research practices (B.C. Luitel, personal communication, October 20, 2015). He further explains how such a transformation enables the learner to think about education for sustainable development of the professionals like a curriculum developer, teacher educator, and researcher as a lifelong reflective practitioner.

Arriving at that point of my exposure to transformative education and research with specific reference to curricular images and/or shades of curriculum, I began to reflect on my supervisor's views of transformative education for sustainable development of self and others. Perhaps, engaging with such kinds of views, beliefs, and practices enabled me to think about my past as an informative practitioner and reflect on my present as a teacher educator and researcher to develop myself as a transformative curriculum developer, teacher educator, and researcher. In so doing, I focused on studying transformative learning theory (Mezirow, 1978), engaged with discussions and discourses with transformative researchers, and interacted with Jack Whitehead, the father of living theories (Whitehead, 1998) to expand my knowledge and build new perspectives.

I came to realize that critical self/others reflections on personal-professional lives with embodied values of practice (i.e., the values one carries in their lives) can improve practices at the personal level (i.e., transformation at a personal level). Perhaps, in so doing, such personalprofessional engagement could ultimately contribute to transformation at societal levels. To this end, Jack Whitehead cautioned me by asking a simple yet very critical question of the kind, 'How am I improving the way I am doing?'(Whitehead, 1989, 2015). Probably, addressing such questions with a critical reflective lens can not only build self-realization but also can lead the explorer to make meaning of being and becoming a transformative learner within a particular context.

Thus, such kind of reflective practice in one's life can influence one's own learning and learning of others with whom one lives and works. There, I came to realize that I as a reformative curriculum developer (in my own areas of interest such as Instructional and Communication Technology (ICT) in Education) at my home university before joining a group of transformative curriculum developers at KUSOED, needed to explore self/beyond with innovative ways of knowing as opposed to the paradigms of informing and reforming education 
and research. Informative and/or a reformative paradigm was likely to lead a curriculum developer as a researcher or a knower to rely on predefined and tested ways of thinking and doing things as a clerk/researcher (the metaphor of researcher as a clerk). Whereas a transformative paradigm using unconventional approaches such as imaginative and critical ways of knowing would liberate researchers to create new knowledge (i.e., serving the purpose of emancipatory interest of education to transform self and beyond).

Thus, using such a transformative paradigm through self/others critique on my own curricular engagements at different levels (for the sake of improvement at a personal level as a curriculum developer and a practitioner) with my own embodied values of intention, humility for humanity, caring with ecological consciousness, love and peace, which I claim to live with and which in/directly also influences self/others' learning could enable me to create my own living-theory of being and becoming a transformative curriculum developer. With this thinking, I began to reflect on my praxis and my embodied values of practices in my curricular practices at both the classroom level (as a practitioner) and curriculum development level. There, I came up with a host of questions to address through a transformative research paradigm for my doctoral study. For example, the questions of the kind, who am I (i.e., as a curriculum developer, implementer, and reflective practitioner) (Palmer, 2007); and in what ways my embodied values influence my own learning and learning of my students (at university level and the influence of their learning on others) and my colleagues where I live and work (Whitehead, 1989)? Hence, to develop a critical understanding of the teacher education curriculum in my own context, I used a unique methodological positioning in my doctoral project.

\section{Methodology}

I have drawn my research methodology and method of inquiry from within multiparadigmatic design space by purposefully choosing (1) Interpretivism (2) Criticalism (3) Postmodernism and (4) Integralism within holism as my data referents (Luitel, 2009, 2012; Merriam \& Kim, 2012; Taylor, Taylor, \& Luitel, 2012). Thus, these paradigms as referents (i.e., the supporters to explain my ideas in the light of philosophical views on ontological, epistemological and axiological standpoint) enabled me to make meaning of my beliefs, views, and practices of curriculum development and application of curricular views in my teaching as a practitioner. Within this space, I have come up with auto/ethnography as a key methodological referent and have used multiple genres and logics to capture key moments of my lifeworld as a curriculum developer and researcher in the form of narratives (Adams, Jones \& Ellis, 2015; Luitel \& Taylor, 2009), critical reflections (Brookfield, 1995, 2012) and imaginative expressions as multiple methods to name a few.

In this paper, I focus on autobiographical self-reflection on curriculum development and on my teaching by embracing multiple images of the curriculum (Rahmawati \& Taylor, 2015). In so doing, I embrace the notion of high deep ${ }^{1}$ as a way of raising consciousness through writing as a therapy and a way of knowing and envisioning teacher education with a morphing view of education in the context of Pakistan. Perhaps, these self-reflections enabled me to make sense of practices with the lens of seeing again which Donald Schon calls reflection-on-action (1983). Whereas critical (self)reflection (Brookfield, 1995, 2012; Kreber, 2012) enabled me to move forward with new perspectives emerging from the process of going

\footnotetext{
${ }^{1}$ I used the term 'deeply-high' to mean that 'thinking deeply' can lead to consciousness raising and it seems the first and foremost important factor that transformative research needs to practice and 'thinking high' comes as a result of deep thinking and vice versa, which enables one to envision consciousness.
} 
back (for seeing again, critiquing on existing practices and meaning-making), coming forward (with new learning with new perspectives) and looking into future practices with visions.

With this line of thought, I came up with five key visions (i.e., curriculum as montage, pedagogies as critical creative, assessment as thorough learning, research as multiparadigmatic, and leadership as transformative) for transformative teacher education for a sustainable future. However, here in this paper, I focus on one of the key visions i.e., curriculum as montage. Within curriculum as montage, there are both conventional as well as unconventional images which explain three forms of education as informing, reforming and transforming. Thus, my vision of developing a curriculum as montage (i.e., Luitel's view of curriculum) includes all conventional as well as contemporary images of curriculum (2009) such as (1) curriculum as currere (Pinar, 2004, 2012), (2) curriculum as experience and reconstruction (Dewey, 1902), (3) curriculum as content, a set of learning outcomes, cultural reproduction, and planned activities (Schubert, 1986). Perhaps, developing such visions demands to focus on reflectionfor-action (Thompson \& Pascal, 2012), which usually would not be possible to develop without building on reflections in action and reflection on actions. So, I want my readers to think about their own beliefs, perspectives, and practices to reflect critically, re/view their own positionalities (theoretically in the form of their beliefs as well as practically in the shape of their everyday practices within their fields) and come up with their own autobiographies of professional lifeworlds. In so doing, they can transform their practices which had been unchallenged previously, with canonical epistemological paradigms of knowing (i.e., knowing as blindly following).

In this paper, I capture key moments of my lived experiences through an autobiographical genre to bring such deep-seated problems and issues of conventional images of curriculum as subject matter, set of discrete tasks, etc. (Grundy, 1987; Schubert, 1986). Moreover, I critique the limitations of reformative images of curriculum as reconstruction and envision a transformative curriculum as currere and montage as one of the key areas of transformative teacher education and research practices in Pakistan.

\section{Curriculum Images and its Implications for Education for a Sustainable Future}

This critical engagement enabled me to come up with my learnings within three domains of curricular positions in the light of three interests of education. These are (1) informative image of the curriculum, which according to Jurgen Habermas, falls within the technical interest of education, (2) reformative images of the curriculum with a practical interest of education, and (3) transformative image of the curriculum with an emancipatory interest of education (1972).

\section{Informative Images of Curriculum}

On a Monday morning some ten years ago, I was teaching a subject named Instructional and Communication Technology (ICT) in education at my home university. There I came to know that my university demands to deliver the course content which is already prepared by the higher education commission of Pakistan for the university teachers with specific learning outcomes. It was designed and developed by some educationists with the notions of curriculum as subject matter, set of discrete tasks, a set of specific learning outcomes, and curriculum as a reproduction (Grundy, 1987).

Honestly speaking, I was unaware of these images of the curriculum and the implications for my students learning at that time, but I was probably happy to go with that prepared content (e.g., a set of discrete tasks and some intended learning outcomes of the course) to rely on for bombarding on the minds of my learners with a conventional teaching approach as telling. Perhaps, without proper training in the teaching profession, no one is 
expected to demonstrate an empowering and liberating view of education, particularly in colonized countries. Here, when I reflect on the implications of employing such kinds of curriculum images, I come to realize that I was having a narrowly conceived view of curriculum (i.e., a curriculum that I had to follow with some set of topics and subtopics within a limited period). It could reproduce the same stuff at the time of a student's semester exams to get promotions to the next level.

Moreover, I can realize how miserable are those (university) teachers who are supposed to just follow a course content to teach. In Pakistan, perhaps like other developing countries which had or had been affected by the colonization, interestingly, there is no need for teacher training after getting a formal degree (i.e., an M.Phil. or a Ph.D.) in a particular discipline to teach. Thus, having a simple degree in a particular discipline is more than enough to enter into the teaching profession at a Pakistani higher educational institution.

This means that there is no need to know for teachers hiring authorities about what kind of curricular exposure a university graduate is having and what would be its implications for students learning to experience with these plane degree graduates (i.e., fresh graduates without any teaching experience) as teaching force. That could be one of the reasons that the teaching profession in Pakistan is considered the least important and neglected profession. One of the obvious examples that can give a vivid picture of its miserable condition is the lowest budget allocations for education in the county (i.e., around or even less than $2 \%$ ).

\section{Reformative Images of Curriculum}

Struggling with conventional images of the curriculum during my primitive period of teaching at university finally enabled me to join a team of educationists at the higher education commission of Pakistan to reform the curriculum. This could be one of the hot weekends of July 2011, when I reached hotel Marriott in Karachi where I could meet other fellows from different universities of Pakistan who were selected to join training on ICT curriculum. In the first phase of training, we had been exposed to the limitations of a conventional image of curriculum and built the basis for bringing some improvements in the existing conditions of the curriculum. However, a contemporary view of curriculum as experience and curriculum as social reconstruction was found to be more interesting.

After being exposed to some literature and reflections on the conventional images of curriculum, I (perhaps, my other colleagues as well) thought to be an expert in the field of ICT in education who can bring a huge change in teaching-learning conditions by embracing a modern view of curriculum. In the second phase, I, along with other course participants of the reforms in the curriculum team, was engaged with designing and developing content that was more resourceful as compared to a conventional view of curriculum, as I discussed above.

Recapitulating my experiences during my job at the university as an educator, I came to realize that a fixed image of the curriculum which asserted curriculum as a subject matter/written document and also a set of discrete tasks, was in practice. While working with the other teacher educators in the university, I realized that there was hardly any space for me to re/conceptualize curriculum (Karseth \& Sivesind, 2011; Porfilio et al., 2015; Schubert, 1986) within a particular socio-cultural context to enable learners to think and link beyond the classroom, their real-life situation. Perhaps, such a limited view of curriculum as an informing document could not enable me to develop a curriculum based on my own experiences of teaching/learning within my teaching context (Fuchs, 2009). I came to realize myself as a tool to handle curriculum content as informing so as to achieve some predetermined learning outcomes. That realization led me to ask a question like, 'In what ways has the nature of informative curriculum been colonizing other teacher educators and me in Pakistan?' 
There I came to know that the existing tradition of university teaching encouraged me to cover the specified teaching contents in the given time frame. I, thus, began to feel that I had to work within a culturally imposing environmental setting of the university till the completion of my probationary period. With this realization, while working as an educator in the university, I came across many challenges of one-size-fits-all images of the curriculum. Curriculum as a content, a set of discrete tasks, and cultural reproduction (Schubert, 1986) were the images of curriculum that strictly governed classroom pedagogy, learning outcomes, and also assessment practices. Hence, I realized that such a view of the curriculum was perhaps a source of limiting views towards teacher education. It gave me the impression that the curriculum has an objectivist agenda. Now, I discuss in detail how a conventional image of curriculum influences pedagogical and assessment practices.

\section{My Role as a Reformer}

While working with the curriculum development team, attending workshops and conferences on teaching, learning, and research, and attending a month-long training course for professional teacher educators ${ }^{2}$, I got many opportunities that enabled me to challenge an informative curriculum agenda. Perhaps, my engagement with professional development programs like training strengthened my notion of challenging the status quo in teaching and learning practices. Perhaps, this experience helped me to reflect on my own contributions at universitylevel teaching and research engagements and enabled me to ask questions like: How can I better help my students in their learning? How am I improving the way I am teaching (Whitehead, 1989, p.1, 2015)?' These questions appeared to be more fruitful in developing my own capacities in facilitating my learners.

My personal and professional works nurtured me to grow with some queries and led me to make a plan for my doctoral study. However, it was mandatory to complete the first three years of service at the university to go for further study. At the same time, I was also engaged with reform activities which led me to think seriously about the changes which I was experiencing within my cultural and academic settings. While working for a reformative curriculum, I came with the concepts like student-centered approach ${ }^{3}$, assessment as 'for' learning. I also came across many loopholes of reforms in teacher education in Pakistan, such as the least attention towards improving the practices of teacher educators, centralized curriculum as an agenda of cultural reproduction, curriculum as a set of discrete tasks, and imposed program of learning outcomes (Ali, 2011). The reformative curricular program also highly focused on physical resources development which was necessary but utterly insufficient to meet the purpose of transforming teachers.

\section{Envisioning as Transforming Self and Others}

Arriving at this point, I begin to reflect critically on my practices that have enabled me to envision an empowering and inclusive view of teacher education and research practices that can be helpful for transformative educational leadership at different levels of my roles in teaching/learning and research practices (Habermas, 1972). Here, this envisioning has further enabled me to ask the question- in what ways my emergent soulful inquiry within multiparadigmatic research design space (see more at https://ejolts.net/node/287) enabled me

\footnotetext{
2 A special course on professional teacher education focusing on effective pedagogies for culturally diverse learners in which teacher educators from 13 countries around the globe attended at Etisalat Academy Dubai back in 2010

3 Somewhat learner-centered teaching with many limitations i.e., lack of resources, lack of administrative support to work with leaner-centered activities and time constraints etc.
} 
to understand informing and reforming the state of narrowly conceived and culturally disempowering nature of teacher education and research practices through different lenses, and my back and forth virtual traveling and mental catharsis to develop a transformative intent of teacher education and research practices in Pakistan (Saldana, 2015, p.4)?

Here, I begin to realize that the philosophy behind transformative teacher education and research practices seems to be embedded within the notions of the paradigm shift in thinking, believing, and acting (Mezirow, 1978, 1990, 2012). To me, paradigm shifts are highly demanded to create conditions for teachers, teacher educators, researchers, and other stakeholders to revisit, reflect, review, and re/conceptualize the concepts regarding existing practices in education. The question is who will create such conditions to experience a paradigm shift.

Arriving at this point of my analysis on reforming the state of education in Pakistan, I began to think that perhaps one of the answers to the question is to make the teachers as classroom leaders and heads as institutional leaders realize and realistically take wise initiatives. To me, this is not all about changing a curriculum and bringing uniformity throughout the country without considering harsh ground realities (e.g., the country has multiple systems of education with a diverse range of curricular interests in education). Here, I used the term harsh realities to reflect on the political slogan/s (i.e., about reforms in education- one country one curriculum) of the current government of Imran Khan, a graduate from Aitchison College Lahore without realizing multiple ways of the differences. Let us take a very simple example of Aitchison College Lahore (having a per-month fee of around 45,000 rupees by providing an education for leading) and a Madrasa school in a village (around 50 rupees fee with a focus on remembering and understanding basics of religious education).

Looking at this picture and reflecting on the political slogan of reforms in education, is it possible to compare these systems by providing the same curriculum (with a slogan of one county one curriculum) without considering their resources, standards of teaching and learning practices, the exposure of staff and students (to self and the world around them) and the approaches to thinking, believing and acting)? Perhaps, it is to create an environment that focuses to provide equitable opportunities to grow and develop with short, medium, and longterm goals with proper allocation of resources (e.g., the budgetary allocations to meet the needs and demand). It is about to bring all stakeholders, especially teachers, teacher educators, parents, institutional leaders, policymakers at ministry levels, education consultants/experts, and donors (e.g., in developing countries, donors have great influence to bring reforms in education (Khan, 2010) with their own vested interests) together to think about how to bring improvement in educational practices to meet the $21^{\text {st }}$ century demands.

Arriving at this point of my reflections on (the limited yet political agendas of) reforms in education, I began to think about the form of education that could lead my fellow workers and me as a teaching force to take initiatives to understand the very nature of curriculum shares/images and metaphors to make meaning of our engagements with curriculum and its implications for powerful learning. Probably, we all stakeholders need to realize and think about a curriculum that embraces both conventional as well as contemporary images of the curriculum, which Luitel (2009) calls curriculum as mosaic.

To me, one of the solutions of this political agenda of reforms in education can be seen in the form of short term, medium- and long-term engagements with education systems to improve with special focus to embrace innovative approaches to knowing, such as exposing teachers to the multi-paradigmatic research in their respective fields of study. Perhaps, such a paradigm shift in thinking, believing, and performing at the personal level (as a teacher) can lead towards transformative education for emancipation. When I reflect on my own journey of transformative education, it reminds me to re/think about my rigorous engagement to explore self (see, for example, Qutoshi, 2019) that enabled me to explore others (the world around me). 
Arriving at this point of my discourse, I think for a transformative education to embrace cultural-self knowing. However, it does not come with political agendas of reforms in education rather, it comes with a commitment to explore self and others within socio-cultural and socio-pedagogical context (Qutoshi, 2016) with clear intentions of improvements in existing conditions and develop new perspectives by disrupting old held assumptions. Thus, my vision as a researcher/teacher educator is to focus on the process of transformation in self/others' professional endeavor, praxis, behavior, values, disposition, and beliefs. So, I wanted to study the metaphor of curriculum as a mosaic to understand how I could use different images of the curriculum at multiple levels. For example, to help my students by developing (1) lower-order thinking skills with remembering and understanding of the concepts (like reproduction of knowledge) through conventional images of curriculum, (2) middle order thinking skills with a focus on applying and analyzing knowledge, and (3) higher-order thinking skills with evaluating and creating new knowledge. To this end, a holistic view of transformative teacher education program for a country like Pakistan is required that does not simply rely on a transformative curriculum but also needs other areas such as pedagogies engagements, assessment approaches, and leadership practices (see, for example, Qutoshi \& Luitel, 2020/in press).

During my journey of transformative teacher education with a holistic lens, I began to reflect on the literature on the transformative learning theory of Jack Mizerow and the livingeducational theory of Jack Whitehead. There I got an opportunity to interact with Jack Whitehead, the promoter of living theory, to explore what it means to be a living educational theory (Qutoshi, 2016). Here, I realize how lucky I was to have reviews of my chapters on the transformative living theory account and getting feedback on my learning. There, I came to understand that building my views on living-theory perspective enabled me to explain and explore the critical questions of the kind, 'how educational practitioners see the 'influence in their own learning, in learning of others (e.g., learning of their students and colleagues) and 'in the learning of social formation in which they live and work' (Whitehead, 2008, p. 104; Whitehead \& Huxtable, 2016). For me, it makes great sense that conventional, abstract, and de-contextualized theories of teacher education and reforms in education used for reforming teacher education with political yet donor-driven agendas focusing on superficial changes cannot be helpful to make a difference in the lives of self/others in my national context.

Here, I came to realize that to develop my own living theory. I need to develop a clear understanding of what it means by living contradictions. Yes, a living contradiction means the difference between what is believed and performed by a practitioner like me in my case of theory development. Interestingly, one can find a living contradiction by watching his/her own recorded teaching practices like what $\mathrm{I}$ did in my case (see for example https://www.youtube.com/channel/UCmluZt8WjAuTtAgrdMJ1_1Q). With critically selfreflecting on the praxis, I came to identify my embodied values (i.e., the values which are embedded within my actions), and there I could address the issue of living contradiction (Whitehead \& Huxtable, 2016).

With this line of thought, there I used the tools of critical self-reflections to explain my own embodied values of 'intention, humility for humanity, caring with ecological consciousness, love and peace' from within my practices and to find my own living contradiction within my praxis to create my own living-theory (Qutoshi, 2016). Thus, the critical reflections enabled me to imagine transformative teacher education and research practices for my country. Perhaps, exposing my students with such notions of curriculum as mosaic within transformative learning framework (i.e., self-empowerment through critical selfreflection with an emancipatory interest of teacher education) and sharing the learning experiences with my fellow practitioners to whom I work and live in a socio-pedagogical setting would influence their learning to transform. Arriving at this point of my inquiry, I come 
to realize teachers as a leader with notions of transformative leadership as/for emancipation (i.e., how a teacher uses the concept of curriculum as mosaic to lead students towards developing higher order thinking skills) seems fundamental. The realization has enabled me to develop a clear understanding of how a transformative leadership at the classroom level and at institutional level creates conditions of transformative curriculum to experience before thinking about reforms in education with a political slogan (one nation one curriculum) without understanding ground realities of the schools and schooling system in Pakistan.

\section{Funding}

The researcher has not received any financial support for the research and publication of this article.

\section{List of References}

Adams, T.E., Jones, S. H., \& Ellis, C. (2015). Autoethnography. Oxford University Press.

Ali, T. (2011). Understanding how practices of teacher education in Pakistan compared with the popular theories and theories and narrative of reform of teacher education in international context. International Journal of Humanities and Social Sciences, 1 (8), 208-222. http://ecommons.aku.edu/pakistan_ied_pdck/84

Anderson, L. W., \& Krathwohl, D. R. (2001). A taxonomy for learning, teaching, and assessing. Allyn and Bacon.

Bohman, J., \& Rehg, W. (2014). Stanford encyclopedia of philosophy: Jurgen Habermas. http://plato.stanford.edu/entries/habermas/

Brookfield, S. (1995). Becoming a critically reflective teacher. Jossey-Bass.

Brookfield, S. (2012). Critical thinking and transformative learning. In E.W. Taylor, P. Cranton \& Associates, The handbook of transformative learning: Theory research and practice (pp. 131-146). Jossey-Bass.

Freire, P. (1968). Pedagogy of the oppressed. Seabury.

Grundy, S. (1987). Curriculum: product or praxis. The Falmer Press.

Habermas, J. (1972). Knowledge and human interest ( $2^{\text {nd }}$ ed.). Heinemann.

Karseth, B., \& Sivesind, K. (2011). Conceptualizing curriculum knowledge within and beyond the national context. In L. Yates, \& M, Grumet (Eds.), Curriculum in today's world: Configuring knowledge, identities, work and politics (58-67). Rutledge.

Khan, M. K. (2010). Indigenous Model of Higher Education Reforms in Pakistan: Higher Education Quality Assurance Initiatives [Unpublished doctoral thesis]. Punjab University Lahore.

Kreber, C. (2012). Critical reflection and transformative learning. In E.W. Taylor, P. Cranton $\&$ Associates. The handbook of transformative learning: Theory research and practice (pp. 323-341). Jossey-Bass.

Luitel, B. C. \& Taylor, P. C. (2009). Multiparadigmatic transformational research as/for teachers' education: An integral prospective. International Handbook of Science Education. Springer.

Luitel, B.C. (2009). Culture, worldview and transformative philosophy of mathematics education in Nepal: A cultural-philosophical inquiry [Unpublished doctoral thesis]. Curtin University, Perth, Australia.

Luitel, B. C. (2012). A multi-paradigmatic approach to researching lived experiences in Mathematics education: Contemplating possible connections. A paper from an International STEM Research Symposium WISDOMe Monograph \#3. University of Wyoming. 
Merriam, S.B., \& Kim, S.J. (2012). Studying transformative learning: What methodology? In E.W. Taylor, P. Cranton \& Associates. The handbook of transformative learning: Theory research and practice (pp. 56-72). Jossey-Bass.

Mezirow, J. (1978). Perspective Transformation. Adult Education, 28, 100-110.

Mezirow, J. (1990). Fostering critical reflection in adulthood. Jossey-Bass.

Mezirow, J. (2012). Learning to think like an adult: Core concepts of transformation theory. In E. W. Taylor, P. Cranton \& Associates (2012), The handbook of transformative learning: Theory research and practice. Jossey-Bass.

Palmer, P.J. (2007). The courage to teach: Exploring the inner landscape of a teacher's life. Jossey-Bass.

Pinar, W. F. (2004). What is curriculum theory? Lawrence Erlbaum.

Pinar, W. F. (2012). What is curriculum theory? (2nd ed.). Routledge.

Porfilio, B.J., Gorlewski, J., \& Gorlewski, D. (2015). Constructing knowledge: Curriculum studies in action. https://www.springer.com/series/11563.

Qutoshi, S. B. (2015). Auto/ethnography: A transformative research paradigm. Dhaulagiri Journal of Sociology and Anthropology, 9, 161-190.

Qutoshi, S. B. (2016). Creating Living Educational Theory: A Journey towards Transformative Teacher Education in Pakistan [Doctoral thesis]. https://www.actionresearch.net/living/living.shtml

Rahmawati, Y., \& Taylor, P.C. (2015). Moments of critical realization and appreciation: A transformative science educator reflects. Reflective Practice, 16(1), 31-42.

Saldana, J. (2015). Thinking qualitatively: Method of mind. Sage.

Schon, D. (1983). The reflective practitioner: How professionals think in action. Basic Books.

Schubert, W. H. (1986). Curriculum: Perspective, paradigm, and possibility. Mcmillan Publishing Company.

Taylor, P. C. (2008). Multi-paradigmatic research design spaces for cultural studies researchers embodying postcolonial theorizing. Culture Studies of Science Education, 3(4), 881-890.

Taylor, P. C., Taylor, E., \& Luitel, B. C. (2012). Multi-paradigmatic transformative research as/for teacher education: An integral perspective. In B. J. Fraser, K.G. Tobin \& C. J. McRobbie (Eds.), Second international handbook of science education (pp. 373-387). Springer.

Thompson, N., \& Pascal, J. (2012). Developing critically reflective practice. Reflective Practice: International and Multidisciplinary Perspectives, 13, 311-325. https://doi.org/10.1080/14623943.2012.657795

Whitehead, J. (1989). Creating a living-theory from questions of the kind, 'how do I improve my practice?' Cambridge Journal of Education, 19(1), 41-52.

Whitehead, J. (2008). Using a living theory methodology in improving practice and generating educational knowledge in living theories. Educational Journal of Living Theories, 1(1), 103-126.

Whitehead, J. (2015). The practice of helping students to find their first person voice in creating living-theories for education (pp. 247-255). In H. Bradbury (Ed.), The sage handbook of action research ( $3^{\text {rd }}$ ed.). Sage.

Whitehead, J., \& Huxtable, M. (2016). Creating a profession of educators with the livingtheories of master and doctor educators. Gifted Education International, 32(1), 6-25.

Zeichner, K. M., \& Liston, D. P. (1996). Reflective teaching: An introduction. Lawrence Erlbaum Associates.

\section{Suggested Citation:}

Qutoshi, S. B. (2021). Journeying through informing, reforming, and transforming teacher education: Reflections on curriculum images. Journal of Transformative Praxis, 2(1), 8-18. https://doi.org/10.51474/jrtp.v2i1.520 